\title{
Industry-specific determinants of shareholder value creation
}

\author{
John Henry Hall \\ Department of Financial Management, University of Pretoria, Pretoria, \\ South Africa
}

\begin{abstract}
Purpose - Prior studies on determinants of shareholder value creation have reported conflicting and sometimes confusing results. In this study, to obtain more refined and industry-specific results regarding variables determining shareholder value creation, an analysis was performed focusing on different categories of firms or industries.

Design/methodology/approach - Two dependent and 11 independent variables were applied to five different industries to obtain the best set of significant value drivers of shareholder value creation for a particular industry.

Findings - Market value added (MVA) is a better indicator of shareholder value created compared to a market adjusted return. Accounting-based variables (EPS, ROA and NOPAT) are superior to economic-based variables (EVA and ROCE) in explaining shareholder value creation, but results differ, depending on the dependent variable chosen as shareholder value creation measure. For each industry, there is a unique set of variables that determine shareholder value creation; the industrial goods industry has seven significant value drivers, namely, EPS, NOPAT, ROCE, the Spread, EVA, EBEI and REVA, whilst for the food and beverages industry, there were only two significant value drivers (EPS and ROA).

Originality/value - These findings imply that management, analysts and shareholders should, depending on the specific industry in which their firm operates, take into account a more specific set of variables when making their financial decisions, including compensation or reward structuring.
\end{abstract}

Keywords Economic value added, Earnings per share, Industry analysis, Market adjusted return, Market value added, Shareholder value creation

Paper type Research paper

\section{Introduction}

It is one of the business orthodoxies of our age that the main goal of every enterprise is to maximize shareholder value. Even without embarking on the philosophical waters of whether this is indeed the most prudent or ultimate goal of a firm, a question that continually arises is how shareholder value creation can be explained and accurately measured. Finding an answer to this question is increasingly difficult, as the corporate world is constantly witnessing the birth of new shareholder value creation measures and is, therefore, faced with an ever-increasing array of research findings on ways to express shareholder value creation. The main traditional (accounting-based) measures to quantify shareholder value creation are earnings per share (EPS), return on equity (ROE), return on assets (ROA) and dividend per share (DPS). These traditional measures have now been challenged and supplemented by economic-based measures of shareholder value creation, such as economic value added (EVA), market value added (MVA), cash flow return on investment (CFROI), cash value added (CVA) and refined economic value added (REVA). 
Numerous studies have been undertaken in the past few decades to decide which measure best expresses shareholder value creation. Sharma and Kumar (2010) summarize the results of 112 studies on EVA, and Hall (2013) discusses the results of 18 studies on such measures conducted during the period from 1991 to 2011. Possible reasons for differences between the results of these and other studies on shareholder value creation measures seem to be the shareholder value creation measure(s) used, the compilation of the sample, the country on whose data the analysis was conducted and the statistical technique(s) used. Moreover, most of these studies try to explain shareholder value creation, share price or excess market returns in respect of a homogenous sample of companies. Inevitably, these varying and sometimes conflicting findings are not able to provide a firm's management with a clear blueprint or path towards efficient shareholder value creation for that particular firm.

Only a limited number of studies (Biddle and Seow, 1990; Lee and Kim, 2009) have been conducted on a heterogeneous sample of companies, analyzing different industries. The present study expands this research and contributes to the existing literature by analyzing five industries in an analysis of South African data and by incorporating more dependent and independent variables than are usually investigated in previous studies of this nature. The particular focus of this study is to determine whether, for different industries, there are different external shareholder value creation measures that express shareholder value creation best for those industries. In addition, the study attempts to establish whether accounting-based or economic-based internal value drivers are superior in explaining shareholder value creation and whether this is still the case if the external shareholder value creation measure as the dependent variable is changed. The main objective of this research is to establish a set of variables or value drivers that are unique and significant in determining shareholder value creation for a particular industry.

Five different industries are analyzed, using two different shareholder value creation measures as dependent variables, namely, MVA and a market adjusted stock return (MAR), in combination with 11 different independent shareholder value variables. To achieve the main objective of this study, some independent variables were eliminated after the initial analysis by means of a step-wise multiple regression analysis to derive a set of significant independent variables that explain shareholder value creation best for a particular industry. The industries concerned are construction and materials, food and beverages, industrial goods (manufacturing) and retail and technology.

The findings of this study make several contributions to the existing body of knowledge on shareholder value creation measures. First, it was determined that in all five industries under review, MVA is a better external shareholder value creation measure than the market adjusted return. The reason for this originates from the different characteristics of the specific shareholder value creation measure applied; one measure is simply better than another. Second, an unique or specific set of variables that create shareholder value is identified for each of the five industries included in the study; for example, for the industrial goods industry, there is seven different variables that explain shareholder value, namely, EPS, net operating profit after tax (NOPAT), return on capital employed (ROCE), the Spread, which is the difference between the ROCE and the weighted average cost of capital (WACC), EVA, earnings before extraordinary income and tax (EBEI) and REVA, whilst for the food and beverages industry, there is only two significant value drivers (EPS and ROA). The reasons for the differences in value drivers for the different industries are based on the different industry 
characteristics; some industries are more capital intensive, some more labour intensive, whilst some industries are more subject to competition and substitute products. From a practical viewpoint, the results of this study will assist management to know exactly, depending on the industry classification of the firm, where to direct its efforts to maximize shareholder value. Furthermore, shareholders will recognize that each industry has its own specific set of value drivers. Finally, stock analysts and portfolio managers will be made aware of the fact that there are specific differences in variables that create shareholder value for the different types of industries in which they plan to invest and for which they might want to perform share valuations, apply valuation methods or make investment recommendations to their clients.

In the remainder of this paper, a brief overview of the relevant literature is given, followed by a discussion of the research method. An analysis and discussion of the empirical results follow. In the conclusion to this study, recommendations are made, based on the findings.

\section{Literature review}

Shareholder value creation and its measurement are arguably amongst the most frequently researched topics in corporate finance. The principle of "accounting profit" was long been known to and used by management, shareholders and analysts, but a movement beyond accounting profit and towards "economic profit" was initiated decades ago by authors such as Fruhan (1979), Rappaport (1986) and Stewart (1991), who, with his associate Stern, developed and popularized EVA. With the development of economic profit measures such as EVA, MVA, CFOI, CVA and REVA, the battle lines were drawn against the more traditional accounting-based measures, such as EPS, ROE, ROA and DPS. The critical question is then which measure (accounting or economic) is best at explaining shareholder value creation.

The sheer number of research studies conducted on shareholder value creation measures is overwhelming, and the results are bewildering, as it seems that every study's results were affected by factors such as the compilation of the sample, the period under review, the source of the data and even the statistical techniques adopted. An analysis of 18 such studies revealed that 6 different dependent variables and 22 different independent variables had been used in research spanning seven different countries over a period of 20 years (1991 to 2011), revealing no fewer than 11 different independent variables that explained shareholder value creation best in the studies concerned (Hall, 2013). Studies which found economic-based measures to be more useful rather than accounting-based variables included studies by Stewart (1991, 1994), Stern (1993), Milunovich and Tsuei (1996), O'Byrne (1996), Bacidore et al. (1997), Chen and Dodd (1997, 2001), Hall (1999), Worthington and West (2004), Chmelikova (2008) and Lee and Kim (2009). By contrast, studies by Biddle et al. (1997), Salvaiy (1997), Bao and Bao (1998), De Villiers and Auret (1998), De Wet (2005), Ismail (2006), Maditinos et al. (2006, 2009), Kyriazis and Anastassis (2007), Erasmus (2008), Kumar and Sharma (2011), Arabsalehi and Mahmoodi (2012), Abdoli et al. (2012), Mollah et al. (2012), Hall (2013) and Alloy Niresh and Alfred (2014) found that accounting-based variables performed better in explaining shareholder value creation than economic-based measures. It falls beyond the scope of this study to discuss the results of the abovementioned studies in more detail, but it is important to point out that the inconsistencies of their results may lead managers, investors, shareholders and researchers to ask the following questions: 
Why are there so many inconsistencies in the results of these studies? Based on these inconsistent results, which performance measure is actually the best to explain the value drivers of shareholder value creation? More importantly, what can be done to determine with greater certainty a more reliable shareholder value creation measure and value driver for a specific firm or type of firm? Surely, one shareholder value creation measurement cannot be universally applied?

This study aims to address these issues by refining and adding to the data being analyzed. This is achieved, first, by increasing the number of dependent and independent variables to obtain a more concise and specific answer as to which shareholder value creation measure is best for a specific industry. Furthermore, by classifying a sample of companies in different industries (as opposed to keeping them in one homogenous group), it was envisaged that not only would a clearer indication be obtained of which shareholder value creation measure better explains value creation in a specific industry but it would be possible to deduce the value drivers that feature as significant variables explaining shareholder value creation in a specific industry.

In analyzing the results of the abovementioned studies, as well as the results of a study by Hall (2013), a number of dependent and independent variables were identified for use in the present study. All the dependent and independent variables were used in one way or another in the prior studies. The dependent variables for the present study are MVA (market value minus capital used) and the market adjusted stock return (MAR) (a firm's 12-month compounded stock return adjusted for the financial year-end of the specific firm). The independent variables which were regressed against the dependent variables in the present study were EVA (return on economic capital minus the WACC, multiplied by capital); EVA growth (GEVA) (the growth in EVA over two consecutive years); REVA (EVA based on the market value of economic capital instead of the book value of capital); EBEI; NOPAT; NI (the net income attributable to shareholders); ROA; EPS; ROE; ROCE; and the Spread. The independent variables, thus, consist of five economic-based variables, namely, EVA, EVAgrowth, REVA, ROCE and the Spread. The remaining six independent variables are accounting-based measures.

To achieve the objectives of this study, the following hypotheses were developed and tested:

H1. Whether market value added or market adjusted stock return is the best shareholder value creation measure differs between industries.

H2. Irrespective of the industry concerned, the impact of economic-based value indicators of shareholder value creation is higher than that of accounting-based measures.

H3. The internal value indicators (drivers) with the highest impact on shareholder value creation differ between different industries.

H4. The internal value indicators (drivers) with the highest impact on shareholder value creation differ depending on whether market value added or market adjusted stock return is used as the external shareholder value creation measure.

H5. Each industry has a unique set of variables determining shareholder value.

These hypotheses were tested using the methodology described in the next section. 


\section{Research method}

The research method followed is set out below. The various industries that were selected for analysis, the dependent and independent variables, as well as the statistical techniques that were applied, are discussed. The data used for this study were obtained from the iNETBFA database, a South African supplier of high-quality financial data.

\section{Industries}

Firms listed on the Johannesburg Stock Exchange (JSE) for the period 2001 to 2011 were selected. The data set consisted of 192 companies. The industry classification used by the JSE was also applied to identify the different industries. The first selection criterion for an industry to be included in the analysis of this study was based on the characteristics of the industry in comparison to other industries; the goal was to have a number of non-related or different types of industries to analyze, as it was hypothesised that different industries should have different variables that explain shareholder value creation. The second criterion was the number of firms in the industry, as the sample size had to be large enough to provide significant statistical results. Based on these criteria, five industries were selected for analysis in this study, namely, construction and materials (28 firms), food and beverages (19 firms), industrial goods (manufacturing) (61 firms), retail (23 firms) and technology (22 firms).

\section{Dependent variables and independent variables}

The two dependent variables that were identified in the literature study were MVA and MAR. The 11 independent variables, further identified by an "(a)" for accounting-based and an "(e)" for economic-based measures, used in this study were EVA(e), EVAgrowth(e), REVA(e), EBEI(a), NOPAT(a), NI(a), ROA(a), EPS(a), ROE(a), ROCE(e) and the Spread(e). These variables were calculated for all firms over the 11-year period under review. Outliers that fell outside three standard deviations from the mean were discarded.

\section{Statistical model specification}

Most prior studies cited above used ordinary least squares (OLS) analysis for a set of cross-sectional time series data. By applying panel data analysis, observations can be conducted on multiple phenomena over various periods for the same firm (Baltagi, 2008). This results in more reliable regression techniques for the cross-sectional time series data and greatly enhances the validity of regression results. For the current study, the data set is an unbalanced panel. The multiple regression model used to test the information content of the independent variables on the dependent variables, based on panel data regression analysis, was the same as that used by Hall (2013):

$$
\begin{aligned}
\text { mva }_{i t s}= & \beta_{0}+\beta_{1} e v a_{i t s}+\beta_{2} \text { evagrowth }_{i t s}+\beta_{3} \text { reva }_{i t s}+\beta_{4} \text { ebei }_{i t s}+\beta_{5} n o p a t_{i t s} \\
& +\beta_{6} n i_{i t s}+\beta_{7} r o a_{i t s}+\beta_{8} e p s_{i t s}+\beta_{9} r o e_{i t s}+\beta_{10} \text { roce }_{i t s}+\beta_{11} \text { spread }_{i t s}+\varepsilon_{i t s .} .
\end{aligned}
$$

In equation (1) above, $m v a_{i t s}$ is the MVA for Firm $i$ in Period $t$ for Industry $s, e v a_{i t s}$ is the amount of economic value added for Firm $i$ in Period $t$ for Industry $s$ and so on. $\boldsymbol{\varepsilon}_{i t s}$ is a stochastic error term for Firm $i$ at Time $t$ for Industry $s ; i=1$ to $192 ; t=1$ (2001) to 11 (2011) and $s=1$ to 5 for the five different industries: 


$$
\begin{aligned}
\text { mar }_{i t s}= & \beta_{0}+\beta_{1} e v a_{i t s}+\beta_{2} \text { evagrowth }_{i t s}+\beta_{3} \text { reva }_{i t s}+\beta_{4} \text { ebei }_{i t s}+\beta_{5} n o p a t_{i t s} \\
& +\beta_{6} n i_{i t s}+\beta_{7} \text { roa }_{i t s}+\beta_{8} e p s_{i t s}+\beta_{9} \text { roe }_{i t s}+\beta_{10} \text { roce }_{i t s}+\beta_{11} \text { spread }_{i t s}+\varepsilon_{i t s}
\end{aligned}
$$

In equation (2) above, mar $_{i t s}$ is the MAR for Firm $i$ in Period $t$ for Industry $s, e v a_{i t s}$ is the amount of EVA for Firm $i$ in Period $t$ for Industry $s$ and so on. In the final analysis on the data of this study, a backward step-wise multiple regression analysis was performed to determine the significant independent variables for each industry. The model used was specified as follows:

$$
\begin{aligned}
\text { mva }_{i t 1}= & \beta_{0}+\beta_{1} \text { eva }_{i t 1}+\beta_{2} \text { evagrowth }_{i t 1}+\beta_{3} \text { reva }_{i t 1}+\beta_{4} \text { ebei }_{i t 1}+\beta_{5} n o p a t_{i t 1} \\
& +\beta_{6} n i_{i t 1}+\beta_{7} r o a_{i t 1}+\beta_{8} e p s_{i t 1}+b_{9} r o e_{i t 1}+\beta_{10} \text { roce }_{i t 1}+\beta_{11} \text { spread }_{i t 1}+\varepsilon_{i t 1} \\
& \text { mva }_{i t 1}=\beta_{0}+\beta_{1} e v a_{i t 1}+\beta_{5} n o p a t_{i t 1}+\beta_{7} r o a_{i t 1}+\beta_{8} e p s_{i t 1}+\varepsilon_{i t 1}
\end{aligned}
$$

A number of tests were performed to assess the validity of the data. Each sample (industry) was tested and corrected where applicable for serial correlation, stationarity and heteroskedasticity. In the next section, the results from the empirical analysis are presented and discussed.

\section{Empirical results}

The empirical results of this study are discussed in three stages, namely, the model validity, multiple regression results and the step-wise regression results.

\section{Model validity}

To assess the validity of cross-sectional effects, the pooled models (models with a common intercept) are assessed against models with individual cross-sectional terms (fixed effects models).

Table I above shows the re-estimated models. The results indicate that for all

\begin{tabular}{|c|c|c|c|c|c|c|c|c|}
\hline \multirow[b]{2}{*}{ Industry } & \multirow{2}{*}{$\begin{array}{l}\text { Dependent } \\
\text { variable }\end{array}$} & \multirow[b]{2}{*}{ Adj. $R^{2}$} & \multirow[b]{2}{*}{$F$-value } & \multirow[b]{2}{*}{$p$-value } & \multicolumn{4}{|c|}{ Durbin-Watson } \\
\hline & & & & & LDW & DW & UDW & $\mathrm{SC}$ \\
\hline $\begin{array}{l}\text { Construction and } \\
\text { materials }\end{array}$ & MAR & 0.399 & 5.754 & 0.000 & 1.8072 & 1.949 & 2.0971 & No SC \\
\hline materia & MVA & 0.853 & 42.625 & 0.000 & 1.8072 & 2.030 & 2.0971 & No SC \\
\hline Food and beverages & MAR & 0.017 & 1.110 & 0.331 & 1.8072 & 2.222 & 2.0971 & Negative SC \\
\hline Food and beverages & MVA & 0.770 & 22.050 & 0.000 & 1.8072 & 2.292 & 2.0971 & Negative SC \\
\hline Industrial goods & MVA & 0.802 & 35.352 & 0.000 & 1.8734 & 1.774 & 2.0791 & Positive SC \\
\hline Retail & MAR & 0.191 & 2.595 & 0.000 & 1.8072 & 2.131 & 2.0971 & Negative SC \\
\hline Retail & MVA & 0.835 & 35.085 & 0.000 & 1.8072 & 1.849 & 2.0971 & No SC \\
\hline Technology & MAR & 0.148 & 2.15 & 0.001 & 1.8072 & 2.195 & 2.0971 & Negative SC \\
\hline Technology & MVA & 0.609 & 11.330 & 0.000 & 1.8072 & 1.782 & 2.0971 & Positive SC \\
\hline
\end{tabular}
industries MVA has higher explanatory power both in terms of the adjusted $R^{2}$ and the $F$-value, and it is therefore the preferred dependent variable. In all the industries, the combination of the independent variables explains more than 60 per cent of the variation

Table I.Second round fixed effects model estimation 
of MVA. By contrast, the ability of the independent variables to explain the variability in MAR was much lower in each industry, with the explanatory power of the models failing to reach the 20 per cent mark in most cases.

\section{Multiple regression analysis}

In Table I, from the $p$-values for each of the models, it can be seen that for the food and beverages industry, the MAR-based model had to be rejected at both a 5 and 10 per cent level of significance; therefore, in the food and beverages industry, the chosen independent variables do not explain firm performance, based on the shareholder value creation measure MAR. From this finding, it is inferred that for manufacturing-based firms, with a large part of the food and beverages industry also falling broadly into the manufacturing-type category, the chosen independent variables cannot sufficiently explain the variation in performance, based on MAR. In this regard, the MVA-based models perform better, with a 77 per cent explanatory power for the food and beverages industry and an 80 per cent explanatory power for the industrial goods industry. It is also noted that for the construction and materials industry, the MVA-based model provides an explanatory value of 85 per cent, more than twice the explanatory power of 40 per cent of the MAR-based model.

Based on the results of this analysis, it appears that overall, MVA performs better than MAR as an expression for shareholder value created in all five industries, which leads to the conclusion that the first hypothesis has to be rejected, namely, that the shareholder value creation measure that best expresses shareholder investment for different industries differs. The finding of this study, that MVA is consistently a better method to express shareholder value creation in all industries than MAR, contradicts Hall's (2013) finding that MAR was superior to MVA in a totally non-homogenous sample and for capital-intensive firms. Table II contains the results of the regression statistics of the present study.

The regression coefficients show that whilst a number of the models are significant overall, for a number of independent variables, this may not be the case. Again, for models based on MAR, it can be seen that only a relatively small number of independent variables are significant, whilst a larger number of variables in the MVA models are significant at a 5 per cent or a 10 per cent level. In total, there are 12 significant variables for the MAR models and 28 significant variables for the MVA models. This further supports the conclusion that purely based on the number of significant variables, MVA should be the primary choice for analyzing firms when categorised by industry, thereby confirming the rejection of the first hypothesis.

Analysing the independent variables that were significant, it was found that REVA(e) featured six times, ROCE(e) five times, EPS(a) five times and NOPAT(a) five times. This result indicates that there is no clear winning group of independent variables (accounting-based vs economic-based) explaining shareholder value creation. The table also shows that for the shareholder creation measurement MVA, EPS, which is an accounting-based variable, is significant in all industries, making it the only independent variable to display significance in all five industries (although it was not the variable with the highest impact in all industries). This implies that the second hypothesis, which states that economic-based variables have a higher impact in explaining shareholder value creation than accounting-based indicators, has to be rejected. The results of this analysis, thus, indicate that the accounting-based variables 
Table II. Regression statistics for final models.

\begin{tabular}{|c|c|c|c|c|c|c|c|c|c|}
\hline $\begin{array}{l}\text { Independent } \\
\text { variable }\end{array}$ & $\begin{array}{l}\text { Construction and } \\
\text { materials } \\
\text { MAR }\end{array}$ & $\begin{array}{l}\text { Construction and } \\
\text { materials } \\
\text { MVA }\end{array}$ & $\begin{array}{c}\text { Food and } \\
\text { beverages } \\
\text { MAR }\end{array}$ & $\begin{array}{l}\text { Food and } \\
\text { beverages } \\
\text { MVA }\end{array}$ & $\begin{array}{l}\text { Industrial } \\
\text { goods } \\
\text { MVA }\end{array}$ & $\begin{array}{l}\text { Retail } \\
\text { MAR }\end{array}$ & $\begin{array}{l}\text { Retail } \\
\text { MVA }\end{array}$ & $\begin{array}{l}\text { Technology } \\
\text { MAR }\end{array}$ & $\begin{array}{c}\text { Technology } \\
\text { MVA }\end{array}$ \\
\hline \multicolumn{10}{|l|}{ Coefficient } \\
\hline EBEI (a) & 0.000020 & 0.000000 & -0.000010 & 0.000000 & $0.00000 *$ & $0.00001^{*}$ & $0.00000^{* *}$ & 0.000000 & 0.000000 \\
\hline EPS (a) & -0.002160 & $-0.00112 *$ & -0.021650 & $0.0007^{*}$ & $0.0001 *$ & 0.029770 & $0.00298^{*}$ & 0.131470 & $0.00391^{* *}$ \\
\hline EVA (e) & -0.000020 & $0.00000 *$ & 0.000010 & $0.00000 *$ & $0.00000^{*}$ & $-0.00008^{*}$ & 0.000000 & 0.000080 & 0.000000 \\
\hline GEVA (e) & 0.002310 & 0.000990 & $0.05811^{*}$ & -0.000100 & $0.00139 * *$ & $1.39995^{* *}$ & -0.033450 & -5.750020 & 0.062590 \\
\hline NI (a) & 0.000000 & 0.000000 & 0.000000 & 0.000000 & 0.000000 & $0.00007^{*}$ & $-0.00001^{* *}$ & 0.000050 & 0.000000 \\
\hline NOPAT (a) & -0.000040 & $0.00000^{*}$ & 0.000000 & $0.00000^{* *}$ & $0.00000 *$ & -0.000010 & $0.00001^{*}$ & $-0.00042^{* *}$ & 0.000000 \\
\hline REVA (e) & $0.00005^{*}$ & 0.000000 & $0.00000^{*}$ & 0.000000 & $0.00000 *$ & $0.00002 *$ & 0.000000 & $0.00001 * *$ & $0.00000 *$ \\
\hline ROA (a) & -1.191000 & 0.094550 & -1.164140 & $-0.01445^{*}$ & 0.003950 & 0.074070 & $-0.51863^{*}$ & 0.826160 & -0.001360 \\
\hline ROCE (e) & 0.133310 & $-0.00559 * *$ & 0.400820 & -0.000210 & $0.00265^{* *}$ & -0.045650 & $0.13586^{*}$ & $-0.17584^{* *}$ & $0.00152^{* *}$ \\
\hline ROE (a) & 0.039680 & -0.002310 & -0.206050 & $-0.0005^{* *}$ & 0.000050 & 0.011600 & 0.001250 & $0.07117^{*}$ & 0.000300 \\
\hline Spread (e) & 2.038210 & -0.002420 & 2.142180 & 0.004900 & $-0.01448^{* *}$ & 0.049640 & $0.06768^{*}$ & -0.068720 & $-0.00935^{*}$ \\
\hline \multicolumn{10}{|c|}{ Regression statistics } \\
\hline Adj. $R^{2}$ & 0.399 & 0.853 & 0.017 & 0.77 & 0.802 & 0.191 & 0.835 & 0.148 & 0.609 \\
\hline$p$-value & 0.000 & 0.000 & 0.331 & 0.000 & 0.000 & 0.000 & 0.000 & 0.001 & 0.000 \\
\hline DW & 1.949 & 2.030 & 2.222 & 2.292 & 1.774 & 2.131 & 1.849 & 2.195 & 1.782 \\
\hline
\end{tabular}

Notes: *Significant at a \% level; ** significant at a 10\% level; “(a)” refers to accounting-based variables; "(e)” refers to economic-based variables 
have a higher impact on shareholder value than the economic-based variables. This finding corresponds with the findings of studies by Biddle et al. (1997), Chen and Dodd (1997), Bao and Bao (1998), De Villiers and Auret (1998), Ismail (2006), Kyriazis and Anastassis (2007), Erasmus (2008) and Kumar and Sharma (2011). A possible reason for the fact that accounting-based variables is superior compared to economic-based variables in explaining shareholder value creation may be that the market (both investors and analysts) tend to rely on and react to accounting earnings as an indicator of the financial well-being of a company. Management reports accounting or financial results, not only in the financial press but also at analysts' meetings and in presentations.

A scrutiny of the various industries focusing on the MVA model reveals that in the industrial goods industry, eight significant independent variables (three accounting and five economic measures) are important, with ROCE(e) coming out the highest. The retail industry is driven by seven significant variables (five accounting and two economic measures), with ROCE(e) coming out the highest. The food and beverages industry is driven by five significant variables (four accounting measures and one economic measure), with EPS(a) coming out the highest. From these results, one can conclude that for different industries, different variables explain shareholder value and, more importantly, that the internal value drivers with the highest explanation of or impact on shareholder value differ between the various industries. This leads $H 3$ to be accepted.

A number of explanations can be offered for why the various industries have different internal value drivers. First, industries that are more capital intensive (the industrial sector), where the operating leverage has a relative big influence on profitability, would have different value drivers than a labour-intensive industry (such as the retail or technology sectors). Hall (2013) found a difference between the value drivers of capital- and labour-intensive firms. Second, firms or industries that have a higher debt ratio relative to other firms or industries tend to experience a bigger financial leverage effect on profitability, returns and shareholder value creation; therefore, different variables have a significant impact on shareholder value creation. Third, during an economic downswing (such as that experienced since 2008), industries such as construction are more affected than industries with a more inelastic demand for their products, such as food and beverages or the retail industry. Biddle and Seow (1990) also found that factors such as industry entry barriers and product type may account for differences in variables that explain returns in different industries.

Although the results of this study show that the MVA model performs significantly better than the MAR model in explaining shareholder value creation, it would be useful to compare the two models on the basis of the specific significant independent variable(s) (value driver(s)) that have the highest impact (positive or negative) on the dependent variable in each of the industries. In the case of the MAR model, REVA(e), GEVA(e) (twice) and ROCE(e) have the highest impact on the shareholder value creation measurement, MAR. It is noteworthy that all these variables are economic-based variables. In the case of MVA, the variables with the highest impact are ROCE(e) (twice), EPS(a) (twice) and ROA(a). This finding leads to the acceptance of $H 4$, namely, that the internal value indicator with the highest impact on shareholder value differs depending on what measure of shareholder value is being used. The finding that different shareholder value creation measures have different value drivers that have the highest impact on them is consistent with the results reported by Hall (2013), who found that the 
ROA had a positive value for MAR but a negative value for MVA and that the Spread had a higher value for MAR than for MVA. Overall, in the analyses of the various industries, the variables that have the highest impact on shareholder value creation are the following: ROCE(e) appeared three times, GEVA(e) appeared twice, EPS(a) twice and both REVA(e) and ROA(a) once.

To conclude this part of the analysis, the overall performance of the models would suggest that the choice of shareholder value creation measure is affected by the choice of industry that is being analyzed, but it may be useful to consider alternative specifications for these models, particularly focusing on a smaller number of independent variables. To achieve the main objective of this study (to determine a set of significant value drivers for a specific industry), a multiple step-wise regression analysis was performed. Doing so enabled the independent variables with the smallest impact on shareholder value creation to be eliminated in a scientific way to identify a set of significant independent value drivers for each industry.

\section{Step-wise regression analysis}

Based on the results obtained in the analysis above, it was decided to analyze the models with a reduced number of independent variables. In this study, a backward elimination step-wise regression was used to find the final combination of independent variables deemed most appropriate for each industry. In addition, an $F$-test for redundancy was also performed. These results, as well as the model estimation results, are reported in the table below. Based on the results of this analysis, the first four hypotheses were once again tested, as was $H 5$ (Table III).

The adjusted $R^{2}$ values show that for all but the technology industry, models based on the MVA have an explanatory power of 80 per cent or more. In the case of the technology industry, the explanatory power of the MVA-based model is just above 60 per cent. In the case of the MAR, however, models based on this dependent variable have low to very low explanatory power, with all models accounting for less than 20 per cent of the variation in the dependent variable. It is therefore concluded that for all industries, MVA is a more appropriate shareholder value creation measure. This finding again leads to the rejection of $H 1$. It was found in this analysis that for all industries, MVA was the preferred method of expressing shareholder value created. Table IV sets out the coefficients and their significance for each of the estimated models and indicates which independent variables were excluded from each estimation.

In Table IV, it is clear that on average, four independent variables were retained in each model. In most cases, the coefficients are found to be significant at least at a 10 per cent level of significance. In the MVA models, the variable that appears most is EPS(a), which appears four times. The variables NOPAT(a), ROA(a), ROCE(e) and the Spread(e) all appear three times, whereas EVA(e) appears twice. Value drivers that do not appear at all are the GEVA(e), $\mathrm{NI}(\mathrm{a})$ and $\mathrm{ROE}(\mathrm{a})$. In total, 21 significant appearances are recorded, of which 12 are accounting-based variables and 9 are economic-based variables. Based on this analysis, $H 2$, again, has to be rejected. The results of this analysis prove that after the elimination of redundant or non-significant variables, the accounting-based variables still explain most of the external shareholder value measures chosen. The reason for the superior performance of accounting-based variables probably lies in the fact that accounting earnings are reported by firms' managements, feeding the market with accounting information. One should also not 
Table III. Final fixed effects model estimation

\begin{tabular}{|c|c|c|c|c|c|c|c|c|c|c|}
\hline \multirow[b]{2}{*}{ Industry } & \multirow[b]{2}{*}{ Dependent variable } & \multirow[b]{2}{*}{ Adj. $R^{2}$} & \multicolumn{2}{|c|}{ Model significance } & \multicolumn{2}{|c|}{ Redundancy } & \multicolumn{4}{|c|}{ Durbin-Watson } \\
\hline & & & $F$-value & $p$-value & $F$-value & $p$-value & LDW & DW & UDW & $\mathrm{SC}$ \\
\hline Construction and materials & MAR & 0.040 & 7.088 & 0.000 & 0.779 & 0.621 & 1.8072 & 2.019 & 2.0971 & No SC \\
\hline Construction and materials & MVA & 0.851 & 50.715 & 0.000 & 1.613 & 2.103 & 1.8072 & 0.132 & 2.0971 & Positive SC \\
\hline Food and beverages & MVA & 0.776 & 32.211 & 0.000 & 0.471 & 0.893 & 1.8072 & 2.295 & 2.0971 & Negative SC \\
\hline Industrial goods & MVA & 0.803 & 37.577 & 0.000 & 0.391 & 0.815 & 1.8734 & 1.803 & 2.0791 & Positive SC \\
\hline Retail & MAR & 0.193 & 3.031 & 0.000 & 0.937 & 0.479 & 1.8072 & 2.115 & 2.0971 & Negative SC \\
\hline Retail & MVA & 0.837 & 42.886 & 0.000 & 0.668 & 0.676 & 1.8072 & 1.799 & 2.0971 & Positive SC \\
\hline Technology & MAR & 0.162 & 2.6282 & 0.000 & 0.537 & 0.806 & 1.8072 & 2.194 & 2.0971 & Negative SC \\
\hline Technology & MVA & 0.608 & 14.592 & 0.000 & 1.047 & 0.402 & 1.8072 & 1.795 & 2.0971 & Positive SC \\
\hline
\end{tabular}


Table IV. Regression statistics following stepwise reduction of independent variables

\begin{tabular}{|c|c|c|c|c|c|c|c|c|}
\hline Independent variable & $\begin{array}{c}\text { Construction and } \\
\text { materials } \\
\text { MAR }\end{array}$ & $\begin{array}{c}\text { Construction and } \\
\text { materials } \\
\text { MVA }\end{array}$ & $\begin{array}{c}\text { Food and } \\
\text { beverages } \\
\text { MVA }\end{array}$ & $\begin{array}{l}\text { Industrial } \\
\text { goods } \\
\text { MVA }\end{array}$ & $\begin{array}{l}\text { Retail } \\
\text { MAR }\end{array}$ & $\begin{array}{l}\text { Retail } \\
\text { MVA }\end{array}$ & $\begin{array}{c}\text { Technology } \\
\text { MAR }\end{array}$ & $\begin{array}{c}\text { Technology } \\
\text { MVA }\end{array}$ \\
\hline \multicolumn{9}{|l|}{ Coefficient } \\
\hline EBEI (a) & $x$ & x & x & $-0.0001^{*}$ & $0.0114^{* *}$ & x & $x$ & $-0.0002^{*}$ \\
\hline EPS (a) & $\times$ & $-0.001^{*}$ & $0.0008^{*}$ & $0.0001 *$ & $\times$ & $0.0026 *$ & $\times$ & $\times$ \\
\hline EVA (e) & $x$ & $0.0021 *$ & x & $0.0004 *$ & $-0.0737^{*}$ & $\times$ & $x$ & $\times$ \\
\hline GEVA (e) & $\times$ & x & $\times$ & $\times$ & $\times$ & $\times$ & $\times$ & $\times$ \\
\hline $\mathrm{NI}(\mathrm{a})$ & $\times$ & x & $\times$ & $\times$ & $0.0692^{*}$ & $\times$ & x & $\times$ \\
\hline NOPAT (a) & $-0.0432 *$ & $-0.0021 *$ & $x$ & $-0.0003^{*}$ & x & $0.0043^{*}$ & $-0.326 * *$ & $\times$ \\
\hline REVA (e) & $0.0333^{*}$ & x & $x$ & $-0.0001^{*}$ & $0.0249^{*}$ & x & x & $x$ \\
\hline ROA (a) & x & $0.0499 * *$ & $-0.0097 *$ & $\times$ & x & $-0.5263^{*}$ & 0.7395* & x \\
\hline ROCE (e) & $x$ & $\times$ & $\times$ & 0.0026 & $\times$ & $0.1379 *$ & $-0.1839 * *$ & $0.0014^{*}$ \\
\hline ROE (a) & $x$ & $x$ & $x$ & x & $x$ & x & $0.0653^{*}$ & x \\
\hline Spread (e) & $1.9152^{*}$ & $\times$ & $\times$ & $-0.0125^{*}$ & $\times$ & 0.0640 & x & $-0.0091^{*}$ \\
\hline \multicolumn{9}{|l|}{ Regression statistics } \\
\hline Adj. $R^{2}$ & 0.040 & 0.851 & 0.776 & 0.803 & 0.193 & 0.837 & 0.162 & 0.608 \\
\hline$p$-value & 0.000 & 0.000 & 0.000 & 0.000 & 0.000 & 0.000 & 0.000 & 0.000 \\
\hline DW & 2.019 & 0.132 & 2.295 & 1.803 & 2.115 & 1.799 & 2.194 & 1.795 \\
\hline
\end{tabular}

Notes: *Significant at a 5\% level; ** significant at a 10\% level; “(a)" refers to accounting-based variables; "(e)” refers to economic-based variables 
forget that the external shareholder value creation measurement MVA is calculated on the basis of the accounting values contained in financial statements.

A scrutiny of the various industries, focusing on the MVA model, reveals that for the industrial goods industry, there are seven significant independent variables (three accounting and four economic measures), with ROCE(e) coming out the highest. For the retail industry, there are five significant variables (three accounting and two economic measures), with ROA(a) coming out the highest. For the construction and materials industry, there are four significant variables (three accounting measures and one economic measure), with ROA(a) coming out the highest. For the technology sector, there are three significant variables (one accounting measure and two economic measures), with the Spread(e) coming out the highest. From these results, it is possible to conclude that different sectors have different variables explaining shareholder value. Even more importantly, the internal value drivers with the highest explanation of or impact on shareholder value differ for each of the industries. This means that $H 3$ has to be accepted. A number of industry-specific factors, such as barriers to entry, product type, maturity of the industry and the capital versus labour intensity of the industry, influence the internal value drivers that explain shareholder creation best. The results of this study indicate that in the retail industry, ROA has the highest impact. This was to be expected, as the retail industry is labour intensive, with a relatively low investment in fixed assets, compared to the industrial industry.

The results of this study show that of the two dependent variables used for shareholder value expression in this study, MAR and MVA, MVA is the preferred shareholder measurement. The Spread(e), EVA(e) and ROA(a) have the highest impact on the shareholder value creation measurement, MAR. In the case of MVA, the variables with the highest impact are ROA(a) (three times), the Spread(e) once and ROCE(e) also once. This finding regarding the variables selected by means of the step-wise regression as the most significant value drivers explaining shareholder value, leads $H 4$ (that the internal value indicator with the highest impact on shareholder value differs depending on what measure of shareholder value is being used) to be accepted. Overall, in the eight industries, the variables that have the highest impact on shareholder value creation are ROA(a) four times, the Spread(e) two times and EVA(e) and ROCE(e) once each. To address $H 5$ (that every different industry or sector should have a different set of value drivers), Table $\mathrm{V}$ was compiled.

Table V. Significant variables per industry (using MVA as shareholder value creation measure)

\begin{tabular}{lllll}
\hline $\begin{array}{l}\text { Construction and } \\
\text { materials }\end{array}$ & Food and beverages & $\begin{array}{l}\text { Industrial goods } \\
\text { (manufacturing) }\end{array}$ & Retail & Technology \\
\hline EPS (a) & EPS (a) & EPS (a) & EPS (a) & \\
ROA (a) & ROA (a) & ROA (a) & \\
NOPAT (a) & & ROPAT (a) & NOPAT (a) & \\
& & ROCE (e) & ROCE (e) \\
EVA (e) & & Evread (e) & Spread (e) & Spread (e) \\
& & EBEI (a) & & \\
& & REVA (e) & &
\end{tabular}

Notes: “(a)" Refers to accounting-based variables; “(e)" refers to economic-based variables 
Table $V$ shows that the EPS is a significant variable in four industries, whilst a number of variables (NOPAT, ROA, ROCE and the Spread) are significant in three industries. Although their study is not entirely comparable to the current study, Lee and Kim (2009) have shown in an analysis of three different sectors in the hospitality industry that there may also be a difference between sectors in terms of measures that explain shareholder returns. In this study, the fact that EPS appears to be relevant for all but one of the industries underlines once again the importance of earnings as a driver of shareholder value creation. Asset management as represented by the ROA is significant for the construction industry (which is both capital- and asset-intensive), the food and beverages (which is also capital intensive and entails manufacturing activities) and the retail industry, where working capital (inventory and debtors) plays an important role in shareholder value creation. However, the technology sector, which is labour intensive, does not have ROA as a significant value driver: human capital (which is not quantified in the financial statements) is probably a significant determinant of shareholder value. The fact that both the NOPAT and the Spread (essentially return ratios) appear as significant variables in the same three industries (industrial goods, retail and technology) can be explained by the fact that competition amongst firms in those industries appears to be particularly fierce. The merger of South African retailer Massmart with the US retailer Walmart in 2011, which gave the group greater bargaining power in purchases and greater retail rental space negotiation powers, illustrates this point. The ferocity of the competition amongst South African retailers is also evident from a recent report that a South African retailer, Shoprite, instituted legal proceedings against Massmart (Walmart) relating to the products that these two retailers sell in one shopping complex (Watson, 2013).

It is further noteworthy that the industrial goods sector has, by a fair margin, the most significant value drivers (seven) explaining shareholder value creation. This might be because industrial manufacturing firms' financial statements might contain the most complete information to calculate shareholder value creation. A similar argument can be made for the retail industry, with five significant variables. By contrast, for the technology sector, with only three significant variables, probably the most significant value drivers are human capital, patents, trade-marks and goodwill, all variables that are either not quantifiable or are usually excluded from the shareholder value calculation.

It should be noted that whilst there is some overlap in respect of the independent variables for each industry, the most appropriate combinations for each industry are unique. One can therefore conclude that the unique characteristics of each industry necessitate the use of different independent variables to best explain the variations in the shareholder value measurement. These findings lead to the acceptance of $H 5$.

This notion is echoed by Merchant (2014), who states that value creation is not only multi-dimensional but depends on firm-specific factors. Steenkamp (2014) found that the processes and ways in which brand value contributes to firm value differ for different firms. In addition, Fabrizi (2014) found that the chief marketing officer of a company, if correctly incentivised, could contribute more to the value of a company than the chief executive officer, whilst Basuroy et al. (2014) found that executive compensation plays an important role in explaining firm value. A superior supply chain management system could also give a company a comparative advantage in value creation (Ellinger 
et al., 2012). An increase in share prices can be expected with an increased level of corporate social responsibility disclosure (De Klerk, de Villiers and van Staden, 2015).

In summary, the results of the present study show that shareholder value creation measures do indeed differ between industries and that accounting-based variables are superior to economic-based variables in explaining shareholder value. However, the main objective of this study was to investigate whether for different industries, there are different value drivers which determine shareholder value creation. In this regard, it was found that for different industries, there are indeed unique sets of value drivers which have been shown to have an impact on shareholder value. The significance of this finding is highlighted in the conclusion to this study.

\section{Conclusion}

Shareholder value creation and its measurement are arguably some of the most frequently researched topics in corporate finance. One reason for it remaining such a relevant and hotly contested research topic is that researchers and the corporate world continue to generate new shareholder value creation measurements. This study set out to refine the search for the best shareholder value creation measure by not only analyzing a bigger range of shareholder value creation measures than most previous studies do but also conducting an analysis on specific samples as represented by different industries or sectors. The main objective of this study was to find, for each of the specific industries, a set of variables that best explain shareholder value creation for that industry. A literature overview of shareholder value creation measures revealed not only an increase in the number of shareholder value creation measures available but also a bewildering array of studies that attempted to analyze, prove, disprove or provide results and findings to shareholders, industry, academia and the creators of these shareholder value creation measures. The results of the current study are significant, as they fill a gap in literature - prior studies mainly used homogenous samples, in contrast to the current study, which analyzes five different industries with two different shareholder value creation measures, namely, MVA and MAR.

The findings indicate that MVA is preferred in five different industries as a shareholder value creation measure, compared to MAR. The study shows that accounting-based variables (EPS, ROA and NOPAT) are dominant compared to economic-based variables (EVA, the Spread and ROCE) in explaining shareholder value creation. The impact of these variables differs between industries. In addition, the variables that explain shareholder value creation differ when different shareholder value creation measures are used. Finally, the results of this study indicate that for each of the five industries analyzed, there is a unique set of variables that determine shareholder value creation. EPS features as a significant value driver in four of the five industries analyzed in this study. The five different industries analyzed all have a different number of value drivers; for example, for the industrial goods industry, there are seven different variables that explain shareholder value (EPS, NOPAT, ROCE, the Spread, EVA, EBEI and REVA), whilst for the food and beverages industry, there are only two significant value drivers (EPS and ROA).

The research methodology of this study provides a refined method of analyzing shareholder value creation measures. It has been proven that results do indeed vary when different value creation measures are being used and that one will not find the same set of results if different industries are being analyzed. Therefore, a one-size-fits-all 
approach is inadequate, as different industries have different sets of variables that explain shareholder value creation.

Based on the results of the present study, a number of recommendations can be made. First, portfolio managers need to concentrate on MVA, as opposed to a MAR as one of their portfolio selection criteria. In addition, portfolio managers need to take into account the different value drivers of industries in their analyses and recommendations. It has also been established that accounting-based variables, especially EPS, have a high impact on shareholder value creation; it is therefore recommended that earnings reports and announcements should be actively used in considering investment decisions, as the results of the current study show that shareholder value follows earnings.

Second, the results of this study can be used by boards of directors to find ways to compensate their employees in a more fair and equitable manner. For example, based on the results set out in Table $\mathrm{V}$, if the board of directors of a firm in the construction industry wants to reward employees, performance indicators such as the EPS, ROA, NOPAT and EVA can be used, whilst the employees of a firm in the retail industry should be rewarded based on improvements in the EPS, ROA, NOPAT, ROCE and the Spread. At the same time, the value drivers for the different industries as presented in Table $\mathrm{V}$ are those that management should concentrate on when making decisions on the operational effectiveness of their organizations.

Although this paper concentrates only on financial performance measures, managers should design performance measurement systems that are designed to capture information on all aspects of their businesses. In this regard, Bryant et al. (2004) cite research that shows that both employees' actions and intangible assets, neither of which is captured by traditional performance measures, should be included in the assessment of a company's success. Iazzolino et al. (2014) propose that a firm's performance must be measured not only by financial performance measures such as EVA but also through multi-criteria methodologies such as the Balanced Scorecard.

In conclusion, the results of this study suggest that the unique characteristics of each industry determine the optimal choice of shareholder value creation measure for that industry and that each industry requires the use of a unique set of variables to determine shareholder value creation. Each shareholder value creation measure brings with it inherently different features which may be more suited to a particular industry than those of other measures. In this regard, further analysis using more dependent variables (such as Tobin's Q ratio or the market to book ratio) is recommended; as such, research may enhance the chances of finding and refining the search for an optimal set of variables that management can concentrate on to enhance shareholder value creation. Indeed, conducting an analysis of the value drivers of a specific firm might be the ultimate goal in answering the burning question of what determines shareholder value.

\section{References}

Abdoli, M., Shurvarzi, M. and Farokhad, A.D. (2012), "Economic value added vs accounting residual income: which one is a better criterion for measurement of created shareholders value?", World Applied Sciences Journal, Vol. 17 No. 7, pp. 874-881.

Alloy Niresh, J. and Alfred, M. (2014), "The association between economic value added, market value added and leverage", International Journal of Business and Management, Vol. 9 No. 10, pp. 126-133. 
Arabsalehi, M. and Mahmoodi, I. (2012), "The quest for superior financial performance measures", International Journal of Economics and Finance, Vol. 4 No. 2, pp. 116-126.

Bacidore, J.M., Boquist, J.A., Millbourn, T.T. and Thakor, A.V. (1997), “The search for the best financial performance measure”, Financial Analysts Journal, Vol. 53 No. 3 (May/June), pp. 11-20.

Baltagi, B.H. (2008), Econometric Analysis of Panel Data, Wiley, New York, NY.

Bao, B. and Bao, D. (1998), "Usefulness of value added and abnormal economic earnings: an empirical examination", Journal of Business Finance \& Accounting, Vol. 25 Nos 1/2, pp. 251-264.

Basuroy, S., Gleason, K.C. and Kannan, Y.H. (2014), "CEO compensation, customer satisfaction, and firm value", Review of Accounting and Finance, Vol. 13 No. 4, pp. 326-352.

Biddle, G.C. and Seow, G.S. (1990), "The estimation and determinants of associations between returns and earnings: evidence from cross-industry comparisons", Journal of Accounting, Auditing \& Finance, Vol. 6 No. 2, pp. 183-232.

Biddle, G.C., Bowen, R.M. and Wallace, J.S. (1997), "Does EVA ${ }^{\circledR}$ beat earnings? Evidence on associations with stock returns and firm values", Journal of Accounting and Economics, Vol. 24 No. 3, pp. 301-336.

Bryant, L., Jones, D.A. and Widener, S.K. (2004), "Managing value creation within the firm: an examination of multiple performance measures", Journal of Management Accounting Research, Vol. 16 No. 1, pp. 107-131.

Chen, S. and Dodd, J.L. (1997), "Economic value added (EVA ${ }^{\mathrm{TM}}$ ): an empirical examination of a new corporate performance measure", Journal of Managerial Issues, Vol. 9 No. 3, pp. 318-333.

Chen, S. and Dodd, J.L. (2001), "Operating income, residual income and EVA ${ }^{\mathrm{TM}}$ : which metric is more value relevant?”, Journal of Managerial Issues, Vol. 13 No. 1, pp. 65-86.

Chmelikova, G. (2008), "Economic value added versus traditional performance metrics in the Czech food-processing sector", International Food and Agribusiness Management Review, Vol. 11 No. 4, pp. 49-65.

De Klerk, M., de Villiers, C. and van Staden, C. (2015), "The influence of corporate social disclosure on share prices", Pacific Accounting Review, Vol. 27 No. 2, pp. 208-228.

De Villiers, J.U. and Auret, C.J. (1998), “A comparison of EPS and EVA as explanatory variables for share price”, Journal for Studies in Economics and Econometrics, Vol. 22 No. 2, pp. 47-63.

De Wet, J.H.V.H. (2005), "EVA versus traditional accounting measures of performance as drivers of shareholder value - a comparative analysis", Meditari Accountancy Research, Vol. 13 No. 2, pp. 1-16.

Ellinger, A., Shin, H., Northington, W.M., Adams, F.G., Hofman, D. and O’Marah, K. (2012), "The influence of supply chain management competency on customer satisfaction and shareholder value", Supply Chain Management: An International Journal, Vol. 17 No. 3, pp. 249-262.

Erasmus, P. (2008), "The relative and incremental information content of the value based financial performance measure Cash Valued Added (CVA)", Management Dynamics, Vol. 17 No. 1, pp. $2-15$.

Fabrizi, M. (2014), “Chief marketing officer's equity incentives: economic determinants and effects on shareholder value”, European Journal of Marketing, Vol. 48 Nos 9/10, pp. 1757-1781.

Fruhan, W.E. (1979), Financial Strategy: Studies in the Creation, Transfer, and Destruction of Shareholder Value, Irwin, Homewood, IL. 
Hall, J.H. (1999), "Correlating internal and external performance yardsticks in the evaluation of corporate wealth creation”, Meditari Accountancy Research, Vol. 7 No. 1, pp. 123-143.

Hall, J.H. (2013), "Toward improved use of value creation measures in financial decision-making”, Journal of Applied Business Research, Vol. 29 No. 4, pp. 1175-1188.

Iazzolino, G., Laise, D. and Migliano, G. (2014), "Measuring value creation: VAIC and EVA", Measuring Business Excellence, Vol. 18 No. 1, pp. 8-21.

Ismail, A. (2006), "Is economic value added more associated with stock return than accounting earnings? The UK evidence", International Journal of Managerial Finance, Vol. 2 No. 4, pp. 343-353.

Kumar, S. and Sharma, A.K. (2011), "Further evidence on relative and incremental information content of EVA and traditional performance measures from select Indian companies", Journal of Financial Reporting \& Accounting, Vol. 9 No. 2, pp. 104-118.

Kyriazis, D. and Anastassis, C. (2007), "The validity of the economic value added approach: an empirical application”, European Financial Management, Vol. 13 No. 1, pp. 71-100.

Lee, L. and Kim, W.G. (2009), "EVA, refined EVA, MVA, or traditional performance measures for the hospitality industry?", International Journal for Hospitality Management, Vol. 28 No. 1, pp. 439-445.

Maditinos, I.D., Sevic, Z. and Theriou, N.G. (2006), "The introduction of economic value added in the Greek corporate sector", The Southeuropean Review of Business \& Accounting, Vol. 4 No. 2, pp. 1-11.

Maditinos, I.D., Sevic, Z. and Theriou, N.G. (2009), "Modeling traditional accounting and modern value-based performance measures to explain stock market returns in the Athens stock exchange (ATE)", Journal of Modelling in Management, Vol. 4 No. 3, pp. 182-201.

Merchant, H. (2014), "Shareholder value creating strategies for emerging markets", in Pattnaik, C. and Kumar, V.(Eds), Emerging Market Firms in the Global Economy (International Finance Review), Emerald Group Publishing Limited, Bingley, Vol. 15, pp. 147-179.

Milunovich, S. and Tsuei, A. (1996), "EVA in the computer industry", Journal of Applied Corporate Finance, Vol. 9 No. 1, pp. 104-115.

Mollah, S., al Farooque, O. and Karim, W. (2012), “Ownership structure, corporate governance and firm performance”, Studies in Economics and Finance, Vol. 29 No. 4, pp. 301-319.

O’Byrne, S.F. (1996), "EVA and market value”, Journal of Applied Corporate Finance, Vol. 9 No. 1, pp. 116-125.

Rappaport, A. (1986), Creating Shareholder Value: The New Standard for Business Performance, Free Press, New York, NY.

Salvaiy, S.C.W. (1997), "The accounting variable and stock price determination", Studies in Economics and Finance, Vol. 18 No. 1, pp. 26-61.

Sharma, A.K. and Kumar, S. (2010), "Economic value added (EVA) - literature review and relevant issues", International Journal of Economics and Finance, Vol. 2 No. 2, pp. 200-220.

Steenkamp, J. (2014), "How global brands create firm value: the $4 \mathrm{~V}$ model", International Marketing Review, Vol. 31 No. 1, pp. 5-29.

Stern, J. (1993), "Value and people management”, Corporate Finance, Vol. 1 No. 1, pp. 35-37.

Stewart, G.B. (1991), The Quest for Value: The EVA ${ }^{T M}$ Management Guide, Harper Business, New York, NY.

Stewart, G.B. (1994), "EVA: fact or fantasy”, Journal of Applied Corporate Finance, Vol. 7 No. 2, pp. $71-84$. 
Watson, L. (16 October, 2013), "Winkels in Kaapse sentrum veg oor kos en drank (Shops in Cape centre fight over food and alcohol)", available at: http://beeld.com/sake/2013-10-16-winkelsin-kaapse-sentrum-veg-oor-kos-endrank (accessed 17 October 2013).

Worthington, A.C. and West, T. (2004), "Australian evidence concerning the information content of Economic Value Added”, Australian Journal of Management, Vol. 29 No. 2, pp. 201-223.

\begin{abstract}
About the author
Professor John Henry Hall is a Member of the Department of Financial Management at the University of Pretoria in the Republic of South Africa. He has published numerous articles in scholarly journals (some of which have received best paper awards) and has presented research papers at a number of conferences both locally and internationally. He has supervised a number of doctoral and Master's students. John Henry Hall can be contacted at: john.hall@up.ac.za
\end{abstract}

